\title{
Pioneers in the Victorian provinces: veterinarians, public health and the urban animal economy
}

\author{
A N NE HARDY* \\ Wellcome Trust Centre for the History of Medicine at UCL, Euston House, \\ 24 Eversholt Street, London NW1 1AD
}

\begin{abstract}
From the 1850s in Britain, concerns were growing about the role of animals in transmitting disease to man, whether through the food chain or through infection. While London is often seen as providing a model for public health reform, it was the great provincial cities that initiated veterinary involvement in public health in the closing years of the century. The emergence of this new strand of public health activity is the subject of this paper.
\end{abstract}

The concern for public health which emerged in Britain in the 1830s and 1840s had an essentially urban focus, and has for the most part, been viewed historically through the prism of London. ${ }^{1}$ It was in London that the incidence of fever among the poor was first investigated, and from London that Edwin Chadwick co-ordinated his investigation of the sanitary condition of the country's labouring classes. ${ }^{2}$ Although William Duncan was the first medical officer of health to be appointed, at Liverpool in 1848, his example and contribution have been overshadowed by those of John Simon, whose work as first medical officer for the City of London, and later as Medical Officer to the Privy Council, attracted the formidable and scrupulous attention of Royston Lambert. ${ }^{3}$

* An early version of this paper was presented at the 'Shock of the City' strand of 'Locating the Victorians' at the Science Museum, London, in July 2001. I am grateful to Simon Szreter for asking me to give that paper; to Ruth Richardson and John Pickstone for encouragement to publish; and to Sarah Wilmot for constructive suggestions.

1 See, for example, B. Luckin, 'Perspectives on the mortality decline in London, 1860-1920', London Journal, 22 (1997),123-41; B. Luckin and G. Mooney, 'Urban history and historical epidemiology: the case of London, 1860-1920', Urban History, 24 (1997), 37-55.

2 See J.V. Pickstone, 'Fever epidemics and British "public health", 1780-1859', in T. Ranger and P. Slack (eds), Epidemics and Ideas. Essays on the Historical Perception of Pestilence (Cambridge, 1992), 125-48; C. Hamlin, Public Health and Social Justice in the Age of Chadwick (Cambridge, 1998).

3 For Duncan see P. Laxton, 'Fighting for public health: Dr Duncan and his adversaries, 1847-63', in S. Sheard and H. Power (eds), Body and City. Histories of Urban Public Health (Aldershot, 2000), 59-88; G. Kearns, 'Town Hall and Whitehall: sanitary intelligence in Liverpool, 1840-63', in Sheard and Power, Body and City, 89-108; R. Lambert, Sir John Simon, 1816-1904, and English Social Administration (London, 1963). 
It was in London that the first extensive public health organization was established, with the appointment under the Metropolis Local Management Act of some 48 medical officers of health to London vestries in 1855-56, some twenty years before any such requirement was imposed on the rest of the country. ${ }^{4}$ Many of the great provincial towns were slow to accept the need for a public health organization: Glasgow appointed its first medical officer in 1863; Manchester in 1868; Birmingham resisted any such appointment until obliged by law in 1872 .

Once the provincial towns and cities had accepted (or been obliged to accept) the need for public health measures, however, they proved more innovative and forward-looking than the capital. London, with no coordinating central authority before 1889 and with complex residential, industrial and occupational patterns, tended to work with limited, established models of sanitation and disease prevention. The introduction of measures for the notification of infectious diseases, for example, first occurred in the provinces, while London also lagged behind in the municipalization of services and in, for example, the introduction of chlorination for drinking water supplies. ${ }^{5}$ The public health work of the provincial cities remains largely unexplored outside the covers of doctoral theses, and comparisons between action and activities in London and the provinces are few. ${ }^{6}$ The history of urban public health in relation to animals and the development of the veterinary profession has been a grey area in the history of public health, yet preliminary investigation demonstrates that here, as in other areas of preventive medicine and municipal management, the great provincial cities took a lead over London in expanding their administrative concerns and extending the remit of municipal public health.

\section{Animals and the city}

Animals were ubiquitous in Victorian cities, as much or more of an element of daily life as they were in the country. There were the horses, the indispensable cog in the national economy, which provided transport and haulage; there were dairy cattle, which supplied milk to many city

4 A. Hardy, The Epidemic Streets. Infectious Disease and the Rise of Preventive Medicine, 18561900 (Oxford, 1993).

5 On notification, see G. Mooney, 'Public health versus private practice: the contested development of compulsory disease notification in late-nineteenth-century Britain', Bulletin of the History of Medicine, 73 (1999), 238-67, esp. 244. On chlorination, Metropolitan Water Board, London's Water Supply 1903-1953 (London, 1953), 268; N. Smith, Man and Water. A History of Hydro-Technology (London, 1976), 131.

${ }^{6}$ For provincial studies, see the essays in R. Woods and J. Woodward (eds), Urban Disease and Mortality (London, 1984); Sheard and Power, Body and City; also N. Williams, 'Death in its season: class, environment and the mortality of infants in nineteenth-century Sheffield', Social History of Medicine, 5 (1992), 71-94; N. Williams and G. Mooney, 'Infant mortality in an "Age of Great Cities": London and the English provincial cities compared, c. 1840-1910', Continuity and Change, 9 (1994), 185-212. 
dwellers; there were the pigs which supported the domestic economy of the poor; the dogs which ranged the streets; the cats which feasted on the city's vermin; the caged birds which hung from many windows; the fowls, rabbits and pigeons which provided protein and pocket money to anyone who had a corner to keep them in; and the cattle, sheep and poultry that were driven to town-centre markets and slaughterhouses. Yet this menagerie was of little account in the wider frameworks of urban concern, in the management of city wastes and food supplies, in environmental improvement, in the regulation of urban health. Despite the growing British feeling for animals - manifested by pride in prize livestock, by antivivisectionist sentiment, by the growing popularity of the Royal Society for the Prevention of Cruelty to Animals, by a sentimentality that could only flourish in an increasingly urban environment distanced from the realities of daily animal keeping - or, perhaps, because of it, most informed Victorians were slow to make a connection between the health and welfare of animals and the welfare of the state, or between the health and welfare of animals and that of the humans who depended on them for food, labour and companionship. ${ }^{7}$ The disposal of animal carcasses (especially large animal carcasses) and of horse manure were the exceptions. The idea that decomposing organic matter released vapours that generated acute diseases and general illhealth in humans was generally applicable to organic wastes. The disposal of dead animals and of stable litter was a private matter, organized by individual and commercial enterprise but just as cities had to find the means for the disposal of human wastes and domestic rubbish, so of necessity they developed systems for the clearance of manure from the streets, lest the cities go under in decomposing ordures of too many descriptions. ${ }^{8}$

Intimate as were the associations between animals and urban life, the realization that there might be connections between animals and human health was long in coming. Although animal disease became a concern of central government following the disastrous epidemic of cattle plague of $1865-66,9$ it was not until the very end of the century that any significant attention began to be paid to possible direct connections between human and animal disease. The Victorian prescription for public health, as it had evolved by the 1870s, involved clean water supplies, effective sewage and garbage disposal, the reduction of overcrowding, the prevention of sale of adulterated foodstuffs, the manage-

7 For the relationship between animals and man in Britain, see K. Thomas, Man and the Natural World. Changing Attitudes in England 1500-1800 (London, 1983); H. Ritvo, The Animal Estate (Cambridge, Mass. and London, 1987).

8 For an insight into the problems of disposing of street manure and stable litter, see R. Turvey, 'Goods and bads', World Economics, 1, 4 (2000), 8-13; F.M.L. Thompson, Victorian England: The Horse-Drawn Society (London, 1970), 11-12.

${ }^{9}$ J.R. Fisher, 'Cattle plagues past and present: the mystery of mad cow disease', Journal of Contemporary History, 33 (1998), 215-28. 
ment of noxious urban trades and the control of infectious disease. ${ }^{10}$ It was an immense brief, that fully absorbed the energies of urban public health departments, many of which were, indeed, only established following the Public Health Act of 1872. In essence, this was a campaign aimed at sorting out the adverse consequences of unregulated urban growth, and reducing the toll of communicable diseases on the community - infections like typhoid, diarrhoea, scarlet fever, measles and whooping cough, which were perceived to be the result of human carelessness, and which accounted prematurely for thousands of lives every year.

Yet if urban public health departments were preoccupied in sorting out the consequences of man's own activities, there were other factors which contributed to a disregard for potential associations between human and animal disease. Even in the twenty-first century, the full implications for man of animal reservoirs of disease and of the ways in which animal health intrudes on human welfare remain very far from fully realized, despite alarms and excursions in the West over salmonella in eggs, listeria in soft cheeses, BSE, e.coli in farmyards, and foot-andmouth disease. ${ }^{11}$ At the root of this entrenched indifference to the potential for the transfer of disease between man and animals lies the opaque nature of that transfer itself. The major infectious scourges of the animal kingdom - distemper in dogs, cattle plague and foot-and-mouth, sheep rot, liver fluke, bovine pleuropneumonia and swine fever - do not apparently transmit to man. Salmonella and other food-poisoning organisms of animal origin are usually transmitted in apparently wholesome foodstuffs: it was only with the advent of the public health laboratory after 1918 that they began to be commonly related to the ingestion of contaminated foodstuffs. Tuberculosis, tapeworms and trichinosis take long enough to develop that the pathway of causation can be obscure. Of the animal diseases that were known by the Victorians to be transmissible, glanders, rabies and anthrax were all of relatively rare occurrence in man. Moreover, glanders and rabies were transmitted by inoculation - by the entry of infected pus through wounds and abrasions on the skin, by the saliva in the bite of a rabid dog. Anthrax was transmitted by the handling of infected hides and hair, and only very rarely through the consumption of infected meat. These three, it could be argued, were essentially accidental transmissions, which could be avoided by due care and attention. In any general context, they did not represent a large threat to human public health.

Second, based in this opacity of transfer, and in the culture of the Christian religion, there persisted a widespread belief in the distinctive-

10 A. Wohl, Endangered Lives. Public Health in Victorian Britain (London, 1983).

11 For a wider perspective on this problem, see L. Garret, The Coming Plague. Newly Emerging Diseases in a World out of Balance (New York, 1994); T. MacMichael, Human Frontiers. Environments and Disease (Cambridge, 2001). 
ness of the human and animal condition, in the essential difference between man and the brute creation. ${ }^{12}$ As Charles Darwin and his followers knew only too well, it was a deeply entrenched position. ${ }^{13}$ In 1874, the Edinburgh physician Lauder Lindsay noted that: 'There remains an inveterate tendency, even among men of the highest special culture and general intelligence, to differentiate man from all other animals. The majority of men and minds insist on his occupying quite a different zoological platform - in respect equally of his structure, functions, mind, soul and even diseases'. ${ }^{14}$ It was not until the new bacteriology began to uncover the specific agents of disease in the years after 1876 that evidence began to emerge that could begin effectively to establish links between animal and human diseases, and even then, as was the case with bovine tuberculosis, the science could be a matter of serious dispute. ${ }^{15}$

The evidence of bacteriology was gradually to dispel also a third strand of blindness in respect of animal disease. It had long been recognized that animal foodstuffs, both meat and milk, could cause illness in man, but this was attributed to the effects of decomposition - to toxins released in the process of putrefaction. These were known as 'ptomaines' - and ptomaine poisoning remained the popular designation for food-poisoning, even among qualified medical men, into the $1920 \mathrm{~s}^{16}$ The consumption of meat from diseased animals was deplored not on grounds of the possible transmission of disease, but because the flesh of sick animals was thought to decay more rapidly. Although the consumption of meat from diseased or naturally dead animals was often taboo among ancient peoples - the Jews, Phoenicians and ancient Egyptians, for example, excluded the flesh of obviously diseased animals and those which had died natural deaths - such scruples did not, apparently, operate among the people of northern Europe. Although in England such meat was regarded as 'unwholesome', and towns regulated against its sale, records from the medieval period onwards show that sick animals regularly entered the food chain, and that their meat was disguised or treated with preservatives, and sold as sound. ${ }^{17}$ Until well into the twentieth century, naturally dead animals, and animals 'killed to

12 Thomas, Man and the Natural World, esp. ch. 1.

13 D. Worster, Nature's Economy. A History of Ecological Ideas, 2nd edn (Cambridge, 1994), 182; and, more generally, A. Desmond and J. Moore, Darwin (London, 1991).

14 W. Lauder Lindsay, 'Community of disease in man and other animals', British and Foreign Medico-Chirugical Review, 53 (1874), 151. See also H.E. Armstrong,' 'The importance of the study of comparative pathology', Veterinary Record, 1 (1888), 17.

15 M. Worboys, Spreading Germs. Disease Theories and Medical Practice in Britain 1865-1900 (Cambridge, 2000); K. Waddington, "Unfit for human consumption": tuberculosis and the problem of infected meat in late Victorian Britain' (unpublished paper, 2001). On the interpretative issues surrounding the 'effective establishment' of scientific knowledge, see B. Latour, The Pasteurization of France (Cambridge, Mass. and London, 1988).

16 E.B. Dewberry, Food Poisoning (London, 1959), ch. 2; W. Savage, Food and the Public Health (London, 1919), 5-7.

17 Dewberry, Food Poisoning, 5-6. See also J.D.Blaisdell, 'To the pillory for putrid poultry: 
save their lives', continued to enter the human food chain in Britain. As one medical oficer noted, much 'diseased and filthy animal food' was 'surreptitiously brought into consumption'. ${ }^{18}$ And links were made to human illness. Following the seizure of a consignment of putrid meat intended for the manufacture of sausages in 1880, Alfred Hill, $\mathrm{MOH}$ for Birmingham, noted plaintively:

the distribution of this stuff amongst the public [is] liable to cause disorder of the Digestive Organs and diarrhoea, which was the most fatal complaint ... in Birmingham last year. Such food [is] likely to aggravate an epidemic of that kind, and its ulterior effects [are] blood poisoning, producing still more disastrous results, possibly conveying parasitic diseases to the human beings who [eat] it. ${ }^{19}$

Where ill effects were recognized, the decomposition theory could easily accommodate even foods that appeared sound. In the first major recorded outbreak of food-poisoning in Britain, at Welbeck in 1879, the investigating medical officer identified imported American ham as the cause of illness. Although not obviously unsound, the meat, he considered, might in storage have undergone 'some chemical change short of putridity' which had produced sufficient toxins to cause illness without affecting the taste and texture of the product. ${ }^{20}$

Despite the general conviction of the essential differences between man and animals, therefore, deteriorating animal (and indeed vegetable) foodstuffs were a legitimate public health concern. Already in the mid1850s, when London's public health organization was newly established, leading public health campaigners like Benjamin Ward Richardson were drawing attention to the dangers of diseased and decaying meat, and the Medical Officers themselves were registering concern. ${ }^{21}$ George Buchanan, for example, later an innovative Chief Medical Officer, declared in 1856 that any system which did not inspect beasts for disease before slaughter was 'radically vicious' ${ }^{22}$ Yet such opinions had little impact on practice or policy: in reality, the urban meat trade and the wider national agricultural system were too powerful for any minority medical opinion to achieve effective influence. ${ }^{23}$ Urban sanitary controls consisted essentially in seizing and destroying consignments of obviously diseased or decayed meat, and their implementation was locally patchy. When Arthur Newsholme attempted, as Medical Officer of Health, to bring the butchers of Brighton under sanitary control in the early years of the

meat hygiene and the medieval London Butchers, Poulterers and Fishmongers' Companies', Veterinary History, 9 (1997), 114-24.

18 Medical Officer, Annual Report (hereafter MOAR), Birmingham (1880), 29.

19 MOAR, Birmingham (1881), 40.

20 A. Hardy, 'Food, hygiene and the laboratory: a brief history of food poisoning in Britain', Social History of Medicine, 12 (1999), 293-311.

21 Editorial, 'Sale of bad meat in London', Journal of Public Health and Sanitary Review, 2 (1856), 311.

22 MOAR, St Giles Vestry (1857), 34.

23 R. Perren, The Meat Trade in Britain 1840-1914 (London, 1978), 50-135. 
twentieth century, he discovered them to be truly doughty fighters in defence of their own established practices. ${ }^{24}$

For the national public health organization which was created in 1872, then, the surveillance and control of food quality beyond the provisions against adulteration of the Food and Drugs acts, was a matter of lesser moment. Nor was the surveillance of animals and their health a particular public health issue, although animals did cause concern. Many medical officers struggled to abolish the urban pig, on the specific grounds of nuisance. Alfred Hill waged fruitless war against the keeping of fowls and rabbits, considering that they produced a 'devitalisation and vitiation of air which is highly prejudicial', especially as they were only kept in small houses. ${ }^{25}$ It was a difficult task, and made no easier by the fine political shades which clouded the simple sanitary issue:

the difficulty is the greater because it is connected with sentiment; there is a feeling that the habit of keeping birds and certain animals is one to be encouraged as leading to an elevation of taste and morals, or at least of diverting from less desirable amusements and pursuits; it is also sometimes maintained that it is attended with a little profit which proves highly acceptable. ${ }^{26}$

These were not arguments with which Hill was inclined to agree.

Such concerns remained very much a medical matter, however. In professional terms, human public health was the concern of the qualified doctor, and there was no suggestion that health departments should invoke the assistance of experts in animal health to assist them in the task of controlling urban animal populations.

\section{Veterinarians and public health}

For most of the Victorian period, veterinary surgeons were absent from the public health scene. Although the Contagious Diseases of Animals Act (1878) did lead to the appointment of veterinary inspectors, these were concerned almost exclusively with the infectious diseases of animals. Birmingham was one of the first cities officially to appoint a Corporation veterinary officer, but it was many years before his work touched that of the Medical Officer. In the 1880s, for example, it was the inspector of markets who performed meat inspections, although ' $\mathrm{Mr}$ Parker, the veterinary inspector' (under the Contagious Diseases of Animals Acts) was called in to examine a pig dead of swine fever and 'highly dangerous as food' 27

24 J.M. Eyler, Sir Arthur Newsholme and State Medicine 1885-1935 (Cambridge, 1997), 64-72.

25 As long as small houses remained a form of working-class accommodation, so the keeping of small food animals and birds continued. Gilda $O^{\prime} N e i l l$ has recorded of London's East End up to the 1950s, that rabbits, chickens and 'all types of livestock' were commonly kept: 'People lived in houses then and could keep animals': G. O'Neill, My East End. Memories of Life in Cockney London (London, 2000), 209.

${ }^{26}$ MOAR, Birmingham (1880), 21. See also MOAR, Birmingham (1887), 47.

${ }_{27}$ MOAR, Birmingham (1883), 13. 
Calls for greater involvement in the business of human public health had been made by veterinarians from time to time since the $1850 \mathrm{~s}$, but by the 1880 s they were becoming more insistent. Although, as John Fisher has so well shown, the veterinarians were at this time a small and fragmented group, variously educated, emerging from the shadow of the farrier's trade, 'not quite a profession', they were not without professional ambitions. ${ }^{28}$ Jeanne Peterson wrote of the mid-Victorian doctors that 'out of individual ambition and collective effort' they transformed their profession, and a similar process can be seen at work among the veterinarians in the last decades of the century. ${ }^{29}$

The route to professional advancement for British veterinarians lay through the Army, where they performed visible and valued service. Influenced by continental practices, the British Army had adopted a 'hygienic' approach to stable management in the later eighteenth century. ${ }^{30}$ In the years that followed, army veterinarians contributed a number of notable monographs on the care of the horse, such as John Stewart's Stable Economy (1838), and Frederick Fitzwygram's Horses and Stables (1869), a popular treatise that had run to four editions by 1894 . A turning point came in 1875, with the publication of George Fleming's Manual of Veterinary Sanitary Science and Police, a volume which drew significantly on continental veterinary practices, and cited a range of continental writings on the idea of veterinary police. ${ }^{31}$ Far more comprehensive in its approach to animal health than any previous English text, Fleming's work dealt not only with epizootic and contagious diseases among animals but with their prevention and suppression, and argued the necessity of a locally-based 'veterinary sanitary organization' and the importance of veterinary inspection of meat and milk, and of slaughterhouses and horse slaughtering establishments - a subject which was, he noted, 'hitherto utterly neglected, so far as Veterinary Science is concerned' ${ }^{32}$ Fleming's avowed aim in publishing this volume was professional: '. . to to elevate veterinary medicine to its proper position'. ${ }^{33}$ No doubt to this end, one of the principal themes of the book was the 'intimate connexion' between 'public hygiene' and the general welfare of the community with veterinary sanitary science.

As a leading Army veterinary officer, Fleming's voice was an influential one, and not only with his own profession. ${ }^{34} \mathrm{He}$ was also at this time campaigning to convince the medical profession of the dangers of

${ }^{28} \mathrm{~J}$. Fisher, 'Not quite a profession. The aspirations of veterinary surgeons in England in the mid-nineteenth century', Historical Research, 66 (1993), 284-302.

29 J. Petersen, The Medical Profession in Mid-Victorian London (Berkeley and London, 1978), 2.

30 F. Smith, A Manual of Veterinary Hygiene (London, 1887), xvi.

31 G. Fleming, A Manual of Veterinary Sanitary Science and Police, 2 vols (London, 1875).

32 Ibid., vol. 1, viii.

33 Ibid.,' Dedication', vol. 1, npn.

${ }^{34}$ George Fleming (1833-1901) entered the Army as a veterinary surgeon, 1855; Inspecting Veterinary Surgeon, War Office, 1879; Principal Veterinary Surgeon to the Army, 1883-90. See 'The late Colonel George Fleming', Veterinary Journal, new ser. 3 (1901), 307. 
tuberculous meat and milk - a danger which his reading of continental scientific writings, and of veterinary pathology, had convinced him was very real. ${ }^{35}$ Several discussions with medical colleagues were written up in the British Medical Journal, and while there can be little doubt of his sincerity, it is clear that an important secondary concern behind his activities on tuberculosis was the integration of veterinarians into the structure of the British public health organization. ${ }^{36}$ In identifying bovine tuberculosis as a danger to man, and in insisting on the unique qualification of veterinarians to detect the disease in both living cattle and dead meat, Fleming was deliberately seeking to expand the range of employment open to his colleagues, and to establish the scientific and social worthiness of his profession.

The 1870 s were a propitious decade for launching such a campaign. The widening of the franchise under the 1867 Reform Act had stimulated the political interests of a wide section of the middle classes; the Public Health Act 1872 imposed a public health organization on local government throughout England and Wales; and the 1875 Public Health Act redefined and set out their responsibilities in this regard. In this and following decades, British veterinarians began to move into local government, becoming Justices of the Peace, mayors, aldermen and city councillors. ${ }^{37}$ In Manchester, for example, veterinarian Sam Locke became a city councillor, and an influential member of the Public Health Committee. In 1878 the Contagious Diseases of Animals Act required all local authorities to appoint suitably qualified veterinary inspectors, albeit on a part-time basis, for the monitoring and control of cattle plague, bovine pleuropneumonia, foot-and-mouth disease and of imported livestock..$^{38}$

Developments in the national economy, meanwhile, resulted in local authorities acquiring extensive studs of working horses. Well-organized councils increasingly took the work of street scavenging and refuse collection into their own hands, rather than relying on contractors, and this necessitated the purchase, stabling and maintenance of horses. Even more significantly, cities began to invest in urban transport systems. ${ }^{39}$ Council-run horse omnibuses and trams necessitated a huge investment in horseflesh. The allocation for one horse-drawn tram or omnibus was eleven animals, worked in pairs for three hours a day, ${ }^{40}$ and this

35 G. Fleming, 'The transmissibility of tuberculosis', British and Foreign Medico-Chirugical Review, 54 (1874), 461-8; idem, Tuberculosis from a Sanitary and Pathological Point of View (London, 1880).

36 [BMA Annual Conference report] G. Fleming, 'Bovine tuberculosis in relation to public health', British Medical Journal, 2 (1880), 473.

37 F. Somers, 'Present aspects of the veterinary profession', Veterinary Journal, new ser. 3 (1901), 195.

38 Contagious Diseases of Animals Act, 41 \& 42 Vict. c.74, section 42.

39 T.C. Barker, 'Urban transport', in M. Freeman and D.H. Aldcroft (eds), Transport in Victorian Britain (Manchester, 1988), 150-5.

40 W.J. Gordon, The Horse World of London (Newton Abbot, 1971), 18, 22-3; F.M.L. Thompson, 'Nineteenth-century horse sense', Economic History Review, 29 (1976), 65. 
produced a notable expansion in council studs. Glasgow Corporation, for example, which formed its its own Tramways Company in the 1870s, owned 3,572 horses by $1900 .{ }^{41}$ At an average valuation of $£ 35$ per horse, Glasgow's stud represented a considerable investment (of some $£ 125,000) .{ }^{42}$ By contrast the London vestry of St George, Hanover Square, owned just 54 horses in $1883 .{ }^{43}$

It was in this context that a number of the great provincial cities began to appoint their own, full-time, veterinary officers. Initially responsible for the council stables, the remit of these men eventually came to extend far beyond the disease-control activities of the part-time veterinary inspectors. Liverpool was the first to create such an officer as it had been the first to create a Medical Officer of Health appointing the 'fine carthorse judge', R.S. Reynolds, in 1880. Birmingham and Manchester quickly followed, and by 1900 Glasgow, Sheffield, Edinburgh and Leeds had made similar appointments. ${ }^{44}$ In London, by contrast, where the transport system remained in the hands of private companies, the local authorities felt no compulsion to appoint veterinary officers.

It was in this handful of provincial cities that the subject which became known as 'municipal veterinary hygiene' was constructed in the 1880s and 1890s. Elsewhere, the situation remained - in veterinary eyes at least - farcical. William Hunting, who worked for the London County Council in the 1890s, and who edited the Veterinary Record, one of the two major veterinary journals, recorded that while every local authority had to appoint a veterinary inspector under the Contagious Diseases of Animals Acts, there was little consistency in their use or practice. In some districts one vet attended the Corporation horses, while another looked after the sewage farm and a third was inspector under the Act; in one large town different veterinary surgeons acted as meat inspector at the abattoirs, and attended to rabid dogs and glandered horses. 'All is muddle and confusion', Hunting concluded. ${ }^{45} \mathrm{He}$ was especially scathing of the capital, where he spent most of his time performing postmortems on horses for the LCC (he claimed to perform 600 a year: about 12 a week). 'London is perhaps pre-eminent in its veterinary arrangements', he noted in 1899, 'There is a Cattle Diseases Committee of the County Council, not one member of which has any practical knowledge

41 Editorial, 'Stamping out glanders - the Glasgow experiment', Veterinary Journal, new ser. 1 (1900), 181.

42 Values estimated from figures given in Gordon, Horse World, 23, 49. Under legislation suggested in 1899, and enacted in 1907, the maximum compensation for a glandered horse was $£ 25$, but $£ 50$ if post-mortem showed no evidence of disease: W. Hunting, Glanders. A Clinical Treatise (London, 1908), 81-2.

43 Turvey, 'Goods and bads', 12.

$44 \mathrm{~J}$. Malcolm, 'Presidential Address', Conference V (Veterinary Inspectors), Journal of the Sanitary Institute, XL (1919-20), 264.

45 W. Hunting, 'Address to conference of veterinary inspectors', Journal of the Sanitary Institute, 20 (1899), 446. 
of animal diseases, and it has never consulted a MRCVS since it was formed'. And yet, as he went on to emphasize: 'In every large town there are animals capable of infecting human beings with fatal diseases, there is food in the form of meat and milk which should be derived only from sound animals, there are hides, and hair and wool which convey disease. ${ }^{46}$ Hunting, no less than Fleming a quarter of a century earlier, was intent upon integrating a veterinary perspective into urban public health.

\section{Municipal veterinary work}

Veterinary municipal hygiene as applied to anything except horses nonetheless got off to a slowish start. In the early years of the municipal veterinary officer, the Corporation horses remained the focus of attention. The great scourge of the nineteenth-century horse world was glanders (and/or farcy; the two are varying manifestations of the same disease), an infection which, in its acute form, could sweep through studs with devastating effect. Beginning as an unaccountable loss of condition, and signalled above all by fever and purulent discharge from the nostrils, the disease progressed inevitably through loss of appetite, exhaustion and death. ${ }^{47}$ It was, however, an infection whose impact depended crucially on the condition of the horse: well-fed, carefully managed older animals in hard condition, which were not overworked, were highly resistant; young animals, and those poorly fed, hard worked and stabled in unhygienic and overcrowded conditions, quickly succumbed. ${ }^{48}$ Once almost universal, glanders had by the 1880 s become an urban disease, largely as a result of the coming of the railways and the disappearance of the long-distance coaching traffic. A major triumph of Army veterinarians in that decade was the eradication of infection from the military studs: a clear indication that the disease as a whole could potentially be stamped out. ${ }^{49}$ London, Glasgow and Liverpool remained endemic foci for many years, however, and there were intermittent outbreaks elsewhere. In 1892, the annual national loss from the disease was calculated at $£ 46,300$ : a sum which represented the lives of over 2,000 animals. 50

In public health terms, glanders did not present a severe threat. The disease was known to be transmissible to man, and is peculiarly unpleasant and swiftly fatal in its acute form. Annual recorded cases were, however, in single figures, although expert veterinarians consid-

46 Ibid., 444.

47 T. Clifford Allbut (ed.), A System of Medicine, 2 vols (London, 1897), vol. 2, 515.

48 Colonel F. Fitzwygram, Horses and Stables (London, 1869), 330; Editorial, 'The suppression of glanders', Veterinary Journal, 35 (1892), 187; Hunting, Glanders, 76.

49 Extract, 'The presence of glanders in Great Britain', Veterinary Journal, 34 (1892), 284.

50 Editorial, 'Glanders and farcy in horses in Great Britain', British Medical Journal, 2 (1892), 456. 
ered these an understatement. ${ }^{51}$ In its acute form human glanders was usually diagnosed as 'pyaemia', and when chronic as tuberculosis. ${ }^{52}$ In the summer of 1892, however, newspaper publicity for the deaths of two London women, the wives of ostlers, from the disease resulted in a public panic, and demands for a determined attempt at eradication. Even the British Medical Journal noted that it was 'a considerable menace to human life', and that in view of the rising number of cases among the urban horse population, more should be done to control the disease. ${ }^{53}$ Despite regular alarms after 1892, glanders did not become a significant public health issue for human preventive medicine: the danger from the disease was largely confined to those who worked among horses - and horses of a certain type - and the condition did not come to offer urban veterinarians any foothold in the coveted territory of human public health.

That opportunity presented itself only in the closing years of the century. In fact, the veterinarians had even lost ground to medical men in the 1880s. Before 1885, the veterinary inspectors had been responsible for the surveillance of dairy cattle under the Contagious Diseases of Animals Acts. In that year, however, a medical inspector of the Local Government Board identified, as he thought, an infectious fever of cattle which could be transmitted directly to humans through infected milk. ${ }^{54}$ As a result, the Board transferred the duties of dairy cattle inspection to the medical officers of health - an action which outraged the veterinary community, but which was consistent with the belief that human health and disease were matters for the medical profession alone. ${ }^{55}$

This state of affairs persisted for something over a decade, until public concerns over the transmissibility of bovine tuberculosis to man were brought to a head following the first report of the Royal Commission on Tuberculosis in 1898. Doctors and veterinarians both in England and on the continent had expended considerable energy in the years since 1875 in debating the likelihood of such a transmission, but the Royal Commission finally came up with clear experimental evidence that milk from cows with tuberculosis of the udder could and did transmit the disease. ${ }^{56}$ As a result, the Local Government Board took action the following year, amending the Dairies, Milkshops and Cowsheds Order

51 W. Hunting, 'Two diseases of man due solely to animal contagion', Journal of the Sanitary Institute, 23 (1902), 821; idem, Glanders, Appendix 'Glanders in Man', 90-100.

52 Allbutt, System, vol. 2, 513.

53 Editorial, 'Glanders in Great Britain', British Medical Journal, 2 (1892), 320.

54 See PP 1886 xxxi, Medical Officer's Annual Report, Local Government Board, 477-80; Appendix no. 8.

55 F. Smith, Veterinary Hygiene, 3rd edn (London, 1905), 684.

56 J. Malcolm, 'Veterinary dairy inspection', Journal of Comparative Pathology, 14 (1901), 29; PP 1898 xlix, Report of the Royal Commission ... into the administrative procedures for controlling the dangers to man through the use as food of the meat and milk of tuberculous animals, 349; evidence of John McFadyean, qq. 1229-33. See also Worboys, Spreading Germs, 221-7; Waddington, 'Unfit for human consumption'. 
effectively to ensure that qualified veterinary surgeons were appointed as dairy inspectors. ${ }^{57}$ As with so many Victorian sanitary regulations, however, the order was permissive, and its principal effect was in extending the remit of the existing veterinary officers in the great provincial cities. Manchester was the first to take action, obtaining a special act of parliament to deal with the question of tuberculosis and the milk supply in 1899 and making regulations which brought the veterinary officer into direct association with the medical officer of health in the surveillance of dairy cattle. ${ }^{58}$ Other cities followed Manchester's example, and their veterinarians began to evolve a wider and more ambitious remit for themselves. John Malcolm of Birmingham, for example, who had been appointed in 1880 for the explicit purpose of caring for the council's horses, went on to develop considerable expertise in the surveillance of dairy cattle, and at his death, just before his retirement in 1920, was hailed by the veterinary community as one of the leading pioneers of municipal veterinary hygiene. ${ }^{59}$

By 1901, an ideal programme for veterinary public health had been established - among veterinarians at least, even if it was not fully implemented in practice. ${ }^{60}$ First came the management of the horses; then the surveillance of dairy cattle. This included, besides the monitoring of health and disease, management of the surroundings in which the beasts were kept, their lighting, ventilation, cleansing and water supply. Such hygienic sanitary management was regarded as important both in town and country, for cows had traditionally been kept in a state of semidarkness, in the belief that they would lie down and rest more quickly after feeding, and that this increased milk production. ${ }^{61}$ In many of the great provincial cities large numbers were stalled in this way - in Liverpool, for example, more than 6,000 cattle were housed within the city as late as $1900 .{ }^{62}$ Yet the veterinarians' brief remained limited: it was well recognized that the milk supply of towns was 'a purely medical question', and most veterinary officers trod a fine line of professional demarcation in their responsibilities for dairy cattle. ${ }^{63}$ Thus when John Malcolm detected a case of contagious mastitis affecting the udder, he dealt with the cow, stopped the use of her milk, and reported to the $\mathrm{MOH}$. The latter it was who was then on the alert for possible related cases of human disease. ${ }^{64}$

57 Malcolm, 'Veterinary dairy inspection', 29.

58 Smith, Veterinary Hygiene, 3rd edn (1905), 704; MOAR, Manchester (1899), 125-8; Veterinary Surgeon, 'Milk and tuberculosis', MOAR, Manchester (1906), 182.

59 Editorial, 'The late Mr John Malcolm, FRCVS, FHAS', Veterinary Journal, 27 (1920), 403.

60 W.H. Bloye, 'The veterinary aspect of public health', Journal of State Medicine, 10 (1902), 595-600. Compare also the 1st (1887) and 3rd (1905) editions of Smith, Veterinary Hygiene.

61 S. Villar, 'Cowshed inspection', Journal of the Sanitary Institute, 21 (1900), 131.

62 Councillor W. Roberts, in discussion following T.B. Goodall, 'Difficulties of dealing with tuberculosis in cattle', Journal of the Sanitary Institute, 21 (1900), 124-5.

63 Smith, Veterinary Hygiene, 3rd edn (1905), 715.

$64 \mathrm{~J}$. Malcolm, 'Outbreak of disease of the udder in dairy cows (contagious mastitis)', Journal of Comparative Pathology, 11 (1898), 86-8. 
A third area of potential veterinary responsibility for public health, and a far more contentious one than milk, was the meat supply. Once again, it was bovine tuberculosis which brought the issue of action on meat quality to the fore, but the subject had been simmering on the veterinarians' political agenda for some time. ${ }^{65}$ British veterinarians had long been aware that meat inspection, and the inspection of animals before slaughter, by veterinary surgeons, had become established practice in many continental countries, ${ }^{66}$ and felt strongly that they, too, were entitled to claim this as an area of exclusive professional expertise. There was even a native precedent: Edinburgh had employed Thomas Walley, principal of the city's Royal Veterinary College to superintend the city abattoir since 1884 , and Walley was recognized by contemporaries to have been the first in Britain to turn meat inspection into 'a science and an art' ${ }^{67}$ Indeed the Royal Commission on Tuberculosis singled Edinburgh's public slaughterhouse out for special praise: here, 'we witnessed meat inspection carried on more nearly on the enlightened system of the best continental abattoirs than it was our fortune to see in any other part of the United Kingdom' ${ }^{68}$ Yet although many cities were employing meat inspectors by the 1890 s, these were not usually qualified veterinarians, but former butchers, policemen, etc., whose expertise in animal pathology was at best minimal. ${ }^{69}$

It was not until after the Royal Commission report that English cities began to appoint veterinarians as meat inspectors. Manchester alone had done so before the report, at the instigation of Sam Locke, who persuaded his fellow councillors that the veterinary surgeon's special training made him the only person 'really efficient' to inspect the city's meat supply. ${ }^{70}$ Once again, Birmingham, Liverpool, Glasgow and Sheffield followed suit. Meat inspection could become a major municipal preoccupation: at Glasgow an initial team of assistant veterinary surgeon and seven meat inspectors was appointed in the spring of 1900, but proved 'quite inadequate', and had to be augmented by a further two veterinary surgeons and seven inspectors. ${ }^{71}$ But Manchester's example was by no means universally followed: Leeds, for instance, where a wonderful new municipal abattoir had just been constructed, had not employed a veterinary surgeon in connection with it by $1901 .{ }^{72}$

65 Waddington, 'Unfit for human consumption'.

66 Fleming, Manual of Veterinary Sanitary Science, 196-210.

67 T. Walley, A Practical Guide to Meat Inspection (Edinburgh and London, 1890), 1; Editorial, 'The outlook for 1900', Veterinary Journal, new ser. 1 (1900), 3-4.

68 Royal Commission on Tuberculosis, Report, 343.

69 Ibid.

70 Ibid., 4.

71 A.M. Trotter, 'The inspection of meat and milk in Glasgow', Journal of Comparative Pathology, 14 (1901), 85.

${ }^{72}$ Somers, 'Present aspects', 197; for the Leeds abattoir see O. Schwartz, Public Abattoirs and Cattle Markets, trans. G.T. Harrap and L.M. Douglas (London, 1901), Appendix II, 443-8. For the situation in various English and Scottish cities $c$. 1908, see G.R. Leighton and L.M. Douglas, The Meat Industry and Meat Inspection, 5 vols (London, 1910), vol. 4, chs 2-5. 
A fourth, and final, area of public health activity to concern the municipal veterinarians came under the provisions of the Contagious Diseases of Animals Acts, but had wider implications for human public health when considered within the still-lingering framework of the miasmatic conception of disease. This was the supervision of urban knackers' yards, which performed an essential function in disposing of the carcasses of worn-out and dead horses and cattle. The carcasses of large herbivores decompose very rapidly, and it was well understood that dead beasts must at least be disembowelled promptly if atmospheric unpleasantness were to be avoided. As one veterinarian noted wryly: 'If only the human body would putrefy and smell with the same rapidity as that of the herbivore, funeral reform would receive considerable assistance' ${ }^{73}$ Although figures are hard to come by, some 500 large animals were dealt with weekly in London, where one firm with 7 yards handled all such carcasses, suggesting a figure of perhaps 100-200 deaths a week in the larger cities. ${ }^{74}$

In the 1850s, knackering had been a lucrative trade: hides, hair, flesh, blood, bones and hooves all found their respective markets. As Fleming noted in 1875 , 'What would otherwise be a source of embarrassment or a nuisance, is converted into articles of more or less value to the community. Knackers' establishments are, therefore, indispensable in or near towns and cities; their importance is increasing with the population in these, and the number of animals they contain. ${ }^{.75}$ But between 1880 and 1900 , the value of the trade was said to have declined by 50 per cent, as the invention of the dog biscuit and commercial dog 'meal' undercut the trade in dogs' meat; as the import of salted horse meat to the European continent was prohibited; as the synthetic dyestuffs industry did away with the market for blood, and the development of the vegetable and mineral oil industry destroyed that for animal oils. ${ }^{76}$ Although crisis point had not been reached by 1900, the situation was worrying, and many of the big northern towns began to invest in powerful incinerators said to be able to 'burn anything'. When one London veterinarian complained of the difficulty of disposing of small animal carcasses in town, a Manchester colleague retorted that if London had not yet adopted the use of powerful municipal destructors, it was 'high time' it did so. ${ }^{77}$ In this situation, veterinary supervision of knackeries ensured

73 Smith, Veterinary Hygiene, 3rd edn (1905), 718-19.

74 W.F. Shaw, 'The disposal of dead animals from a sanitary point of view', Journal of the Sanitary Institute, 14 (1903), 731.

75 Fleming, Manual of Veterinary Sanitary Science, 592.

76 Shaw, 'Disposal of dead animals', 731-3; see also Fleming, Manual of Veterinary Sanitary Science, 594-601. I have been unable to date the development of the dog biscuit and of dog meal more precisely. In the early 1870 s the term 'meal' referred specifically to oatmeal, which was prepared by owners themselves for mixing with meat: W. Youatt, The Dog, 2nd edn (London, 1874), 34-5, 76.

$77 \mathrm{Mr}$ Wolstenholme, in discussion following Shaw, 'Disposal of dead animals', 738. See also Smith, Veterinary Hygiene, 3rd edn (1905), 718. 
not only that slaughtering was humanely accomplished, but also that the processes of disposal - so essential to the avoidance of nuisance - were efficiently conducted.

\section{Pioneering municipalities}

Veterinary concerns for the efficient management of knackeries constituted the last strand in a low-key but steady campaign by the profession to convince government and the local authorities to employ veterinarians in the enterprise of ensuring human public health. Beginning in the 1870 s, it had effectively achieved little by 1900. It was only as a result of scientific investigation, as expounded through the 1898 Royal Commission report on tuberculosis, that a handful of provincial cities began to integrate veterinarians into the public health organization at the end of the century. Yet the example of these pioneering municipalities and the programme of veterinary public health which their veterinarians evolved at the turn of the century established a new, broader model of public health concern which expanded only slowly, but which persisted until the eve of the Second World War. ${ }^{78}$ In co-opting the veterinary surgeons on to the public health team, cities like Glasgow, Manchester and Birmingham signalled their modernizing, forward-looking approach to public welfare, and their respect for the findings of modern science. At a time when concerns over urban degeneration were rising to a pitch, the recruitment of qualified professionals to monitor urban cattle and meat and milk supplies underlined a belief in the external, environmental causes of human disease and disability. ${ }^{79}$ As unitary authorities, the great provincial cities had in this respect a great advantage over London, whose vast geographical sprawl, highly mobile populations of humans and animals, fragmented administrative structure and dependence for services on private enterprise, inhibited ideas on, and application of, city-wide surveillance of animals and animal foodstuffs. In the project of making a nation of good human animals, the leading provincial cities set an example at the end of Victoria's reign by employing veterinary surgeons to inspect dairy cattle and horse slaughterers, to supervise abattoirs and to monitor meat supplies.

78 Ministry of Agriculture, Farming and Fisheries, Animal Health. A Centenary History 18651965 (London, 1965), 95.

79 On the public health issues surrounding degenerationism, see D. Porter, "Enemies of race": biologism, environmentalism and public health in Victorian England', Victorian Studies, 34 (1991), 160-77. 